\title{
Serum Levels of Matrix Metalloproteinases: Implications in Clinical Neurology
}

\author{
Fredrik Romi $^{a}$ Geir Helgeland ${ }^{b}$ Nils Erik Gilhus ${ }^{a, b}$ \\ a Department of Neurology, Haukeland University Hospital, and bepartment of Clinical Medicine, \\ University of Bergen, Bergen, Norway
}

\section{Key Words}

Matrix metalloproteinases - Multiple sclerosis $\cdot$ Myasthenia

gravis $\cdot$ Stroke $\cdot$ Neurodegenerative disease

\begin{abstract}
Matrix metalloproteinases (MMPs) are zinc-dependent enzymes involved in remodeling extracellular matrix and cellmatrix interactions. A pathogenic role of MMPs in neurological disorders is likely. This paper focuses on serological clinical aspects only. In multiple sclerosis, higher serum MMP-3 is seen during relapses. Lower serum MMP-8 and -9 levels correlate with fewer contrast-enhanced $\mathrm{T}_{2}$-weighted MRI lesions, and serum MMP-9 can be used in monitoring treatment. In myasthenia gravis, serum MMP-2, -3 , and -9 levels are elevated in both generalized and ocular diseases. A proportion of the patients have markedly increased serum MMP-3. In acute stroke, higher serum MMP-9 correlates with larger infarct volume, stroke severity, and worse functional outcome, and serum MMP-3 is significantly lower than in several other neurological disorders and healthy controls. In amyotrophic lateral sclerosis, serum MMP-2 correlates with disease progression, and both serum MMP- 1 and -2 are elevated. In Alzheimer's disease, serum MMP-3, -9 , and -10 are elevated. In migraine, serum MMP-2 is elevated, and also
\end{abstract}

MMP-9 in those patients with migraine without aura. MMP-9 is implicated in the pathogenesis of experimental epilepsy. A pathogenic role of MMPs in these conditions could be related to their ability to degrade extracellular matrix. MMPs may also facilitate autoimmunity.

Copyright $\odot 2012$ S. Karger AG, Basel

\section{Matrix Metalloproteinases}

Matrix metalloproteinases (MMPs) represent a multimember family of zinc-dependent proteases with a wide range of substrates, including extracellular matrix components, cytokines, receptors, and cell motility factors $[1$, 2]. They are recognized as the main proteolytic enzyme group involved in remodeling the extracellular matrix and modifying cell-cell and cell-matrix interactions [3]. MMPs play an important role in regulating organ development including muscles and nerves, maintaining normal physiology in adulthood, and they also take part in repair after injury in the nervous system.

Many different human MMPs have been identified [1]. Based on function and structure, MMPs can be subdivided into 5 groups: (i) collagenases (MMPs-1, -8 and -13); (ii) gelatinases A and B (MMPs-2 and -9); (iii) stromelysins-1

\section{KARGER}

Fax +4161306 1234

E-Mail karger@karger.ch

www.karger.com
(C) 2012 S. Karger AG, Basel

0014-3022/12/0672-0121\$38.00/0

Accessible online at:

www.karger.com/ene
Fredrik Romi

Department of Neurology, Haukeland University Hospital

NO-5021 Bergen (Norway)

Tel. +47 5597 5000, E-Mail fredrik.romi@ @aukeland.no 
Fig. 1. Schematic representation of MMP-9 synthesis and activation. MMP-9 mRNA translocated toward the dendrites is locally translated with the protein eventually localized to secretory vesicles. In response to glutamate-driven neuronal activity, MMP9 is released outside the cell where, through the cascade of proteolytic steps (involving, e.g., furin, MT1-MMP, MMP-2, tPA, uPA, and plasmin), it is transformed from the latent to the active form. Once activated, MMP-9 is quickly inactivated by interactions with its inhibitor TIMP-1. tPA = Tissue-type plasminogen activator; uPA = urokinase-type plasminogen activator; $\mathrm{uPAR}=\mathrm{uPA}$ receptor. (From Michaluk and Kaczmarek [6], with permission from $\mathrm{Na}$ ture Publishing Group.)

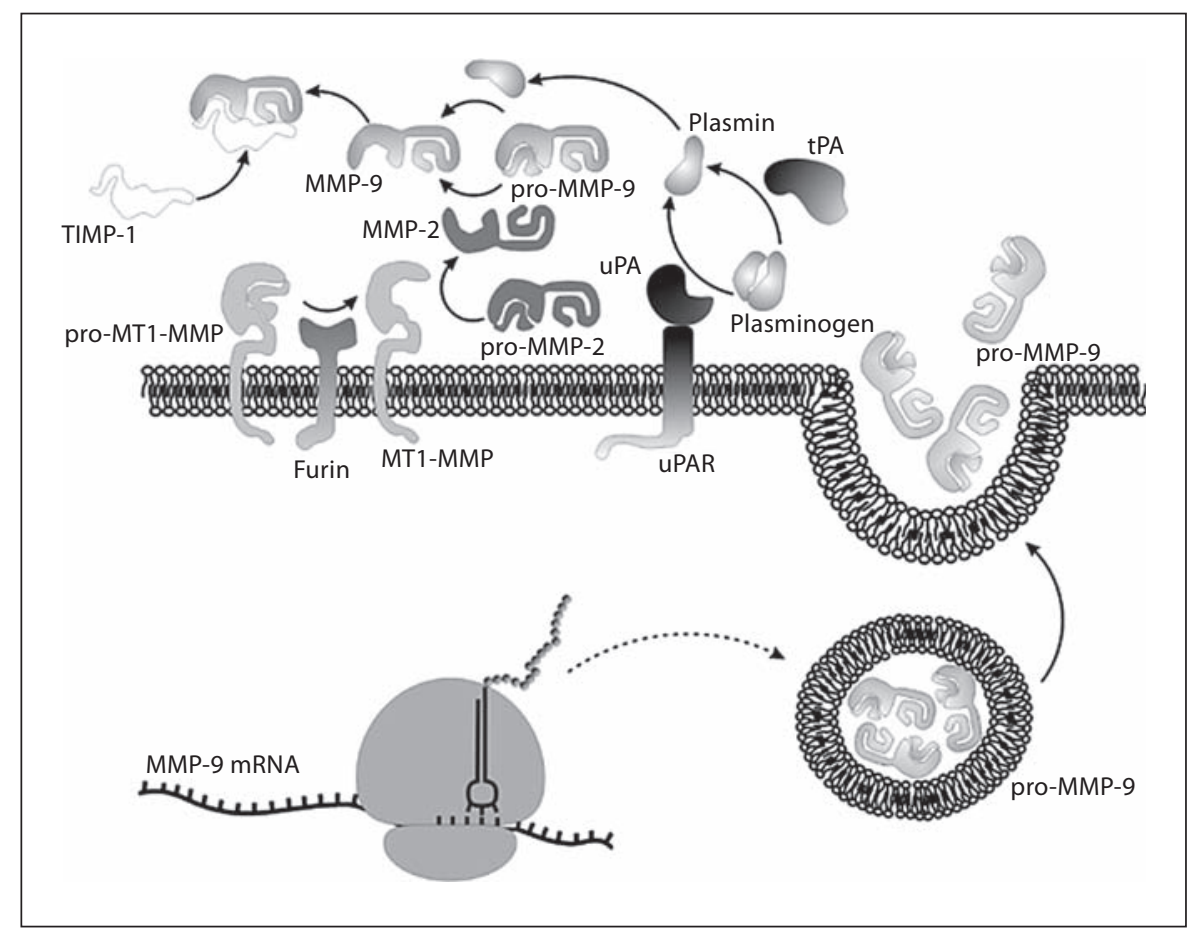

and -2 (MMPs-3 and -10); (iv) a more heterogeneous subgroup containing matrilysin (MMP-7), enamelysin (MMP20 ), the $m m p 20$ gene product, macrophage metalloelastase (MMP-12), and MMP-19 (together making up the 'classical' MMPs), and (v) membrane-type MMPs (MTMMPs-1-4 and stromelysin-3, MMP-11) [4]. Most MMPs are synthesized with a $\sim 20$ amino acid residue signal peptide and are secreted as pro-proteinases consisting of an $\sim 80$-residue $\mathrm{N}$-terminal prodomain followed by the $\sim 170$-residue catalytic domain, which in turn is covalently connected through a 10- to 70-residue Pro-rich linker to a $\sim 195$-residue C-terminal hemopexin-like domain [4]. MMPs are expressed as inactive zymogens. The $\mathrm{Zn}^{2+}$ at the active site of the enzyme binds to the cysteine residue in the propeptide. When the interaction between cysteine and $\mathrm{Zn}^{2+}$ is disrupted, mainly by cleaving the propeptide, the proenzyme is activated $[5,6]$. This activation is controlled by a series of steps involving other MMPs and the plasmin system, as demonstrated in MMP-9 (fig. 1) and MMP-2 (fig. 2). Free radicals, serine proteases, and other activated MMPs are among the factors that convert a proMMP to its active enzyme [1]. When activated, the MMPs can be inhibited by their tissue inhibitors (TIMPs) [6].

The TIMP family includes four different members (TIMPs-1-4), exhibiting 41-52\% sequence identity $[4,7]$. TIMPs have an inhibitory role and also may function as growth factor-like agents. They may also show anti-angiogenic activity [8].

MMPs have catalytic properties due to the presence of $\mathrm{Zn}^{2+}$. The catalytic domains of the MMPs exhibit the shape of an ellipsoid. A small active-site cleft harboring the catalytic $\mathrm{Zn}^{2+}$ is notched into the flat ellipsoid surface and extends horizontally across the domain to bind peptide substrates from left to right [4]. The degrading catalytic activity of MMPs is regulated by TIPMs, striking a balance that is necessary for normal biological function of these enzymes.

The gelatinase members of the MMP family, MMPs-2 and -9 , have traditionally been the easiest to detect using gelatin zymography, and hence there is much more available data on them. Antibodies to both gelatinases and other MMP members have been developed making it even easier to detect MMPs by ELISA. RNA analyses are useful to ascertain MMP expression since primers are available for the majority of MMPs. Using real-time polymerase chain reaction, the majority of MMP members can be detected [1]. Most of these tests are commercially available and easy to use. Since MMPs may also be detected in some healthy individuals, the results from a patient group should always be compared to those from a group of healthy individuals where the cut-off values can be determined. 
Fig. 2. Mechanism of pro-MMP-2 activation. a MT1-MMP on the cell surface acts as a receptor for TIMP-2. TIMP-2 binds via its $\mathrm{N}$-terminal domain to the active site of the MT1-MMP. This binary complex then acts as a receptor for pro-MMP-2, with the TIMP-2 C-terminal domain binding to the C-terminal domain of pro-MMP-2. A free MT1-MMP molecule in close proximity can then cleave the propeptide of proMMP-2, generating an intermediate species. Further proteolysis of the propeptide through an autocatalytic mechanism results in the generation of the fully active enzyme. Activation of pro-MMP-2 in this model is only possible if the TIMP-2 concentration is low, with sufficient TIMP-2 to generate the trimolecular complex but not enough to saturate all the MT1-MMPs required for proteolysis of the propeptide. b At high levels, TIMP-2 will bind to and inhibit all MT1-MMP activity, preventing pro-MMP-2 activation. (From Expert Reviews in Molecular Medicine, with permission from Cambridge University Press.)

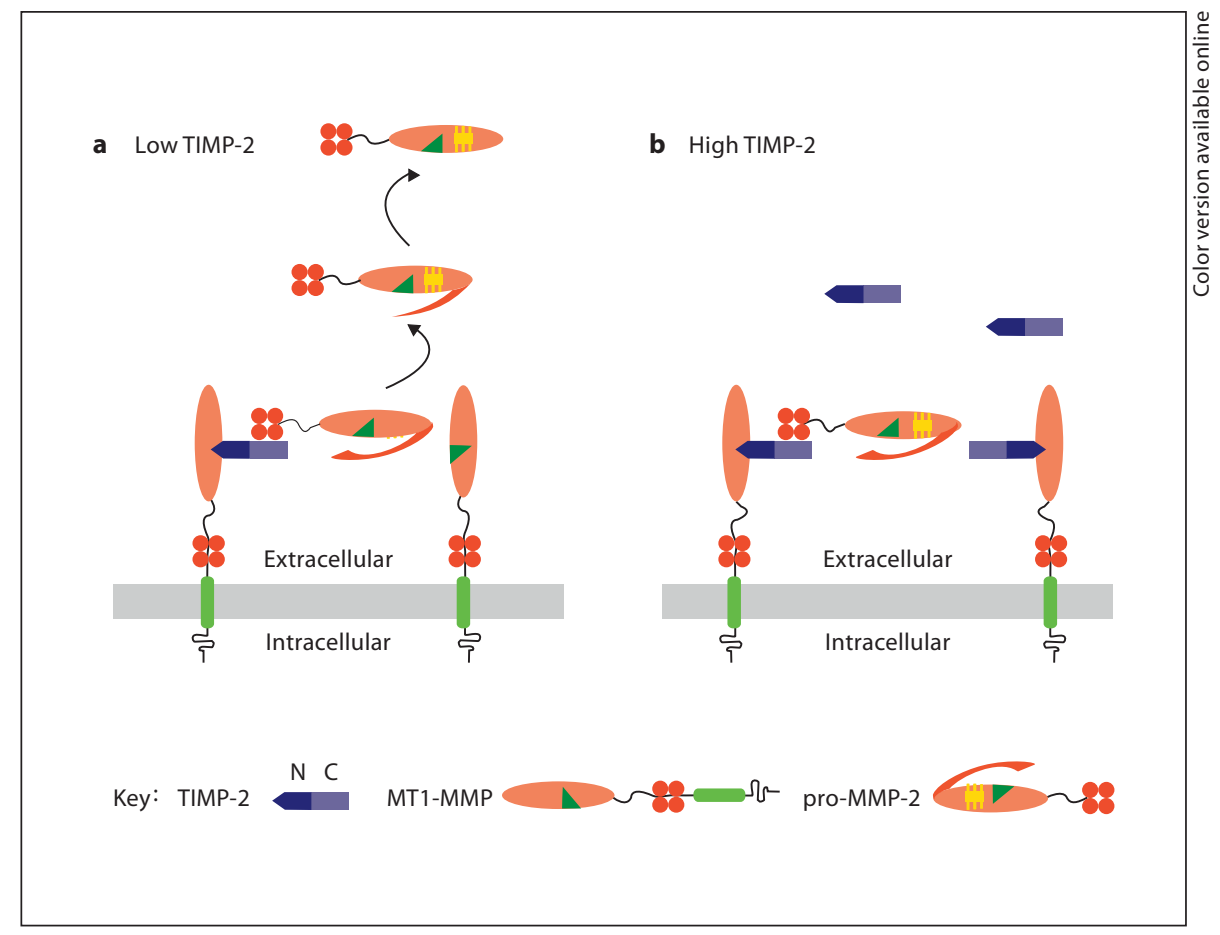

MMPs play an important role in normal function and pathology. In the central nervous system (CNS), for instance, MMP-9 is involved in the myelination process, and the lack of it in MMP-9-deficient mice leads to microcrania. MMPs- 2 and -9 are involved in the repair process following CNS injury [1].

A balance between the degrading matrix MMPs and their TIMPs regulates the turnover of extracellular matrix in all solid organs [9]. A disruption of the MMPTIMP balance may result in diseases such as rheumatoid arthritis (RA), osteoarthritis, atherosclerosis, tumor growth, metastasis, and fibrosis [4]. An altered extracellular matrix metabolism has been implicated in a variety of diseases, and the upregulation of MMPs in several neurological conditions has been associated with pathology $[10,11]$. The production of MMPs is also influenced by genetic polymorphisms. In multiple sclerosis (MS), for instance, the genetic polymorphism of the MMP-9 promoter region was found to influence the susceptibility to MS [12]. A functional polymorphism in MMP-1 has been shown to alter the transcriptional activity of it, resulting in diverse pathological processes [13].

MMPs play a significant role in the pathogenesis of several autoimmune diseases such as RA, systemic lupus erythematosus (SLE) [14, 15], and Sjögren's syndrome [15]. An elevated serum MMP-9 level is found in SLE [16], systemic sclerosis [17], RA [18], and Sjögren's syndrome [19]. Serum MMP-3 is increased in SLE and RA [14, 20]. A pathogenic role of MMPs in these conditions could be related to their ability to degrade extracellular matrix components, exposing self-antigens to the immune system and facilitating autoimmunity in general.

MMP inhibitors have been tested in the treatment of different acute and chronic conditions. MMP inhibitors usually act on the active MMP $\mathrm{Zn}^{2+}$ site and have different mechanisms of action. Some inhibitors contain hydroxamate that chelates the $\mathrm{Zn}^{2+}[21]$, while others contain carboxylic acids, thiols, or phosphorous-based structures [1].

In recent years, advances have been made regarding the role of MMPs in both autoimmune and non-autoimmune neurological disorders. The aim of this paper is to review this role, focusing on current and future clinical implications in selected neurological disorders for which clinical and serological MMP data are available.

\section{Serum Levels of MMPs in MS}

MS is an inflammatory autoimmune CNS disease with a lifetime risk of 1 in 400 . The pathogenesis includes acute inflammatory injury of axons and glia, recovery of function and structural repair, postinflammatory gliosis, and 
neurodegeneration. MS is mediated by autoreactive T lymphocytes with specificity for myelin antigens that trigger oligodendrocyte death associated with axonal loss and neurodegeneration in the CNS $[22,23]$. The clinical course is characterized by episodes with recovery, episodes followed by neurological deficits, and secondary progression [22]. Genetic susceptibility is probably the most important determinant of MS pathogenesis, with HLA DRB1* 1501 present in over $50 \%$ of northern MS patient populations. Environmental differences principally determine the regional variations in disease characteristics. Despite $75 \%$ of MS patients being women, men are more likely to be genetically susceptible [24]. Migration studies show that changes to early environment can greatly affect MS susceptibility [25]. Epigenetic modifications within the major histocompatibility complex are likely to interact with environmental risk factors, causing MS [26].

MMPs are involved in blood-brain barrier disruption and formation of MS lesions [27]. Several MMPs are elevated parallel to increased disease activity in experimental autoimmune encephalomyelitis (EAE) [28]. Increased MMP activity and reduced TIMP levels contribute to a loss of blood-brain barrier integrity. In a clinical MS trial, erythropoietin induced the expression of TIMP-1 in endothelial cells, which helped maintaining blood-brain barrier integrity. The protective effects of erythropoietin were associated with an increase in the number of astrocytes expressing TIMP-1 in the brain and spinal cord in EAE [29]. Decreased serum MMP-8 and MMP-9 levels correlated with a decreased number of contrast-enhanced $\mathrm{T}_{2}$-weighted MRI lesions in MS patients [27]. In the same study, MS patients treated with IFN-betalb showed a reduction in serum MMP-8 and MMP-9 in parallel with disease stabilization. The authors concluded that serial measurement of MMPs and other inflammatory mediators may serve as sensitive markers for therapeutic response to IFN-betalb during the first year of treatment. Another study similarly suggested MMP-9 as a factor in MS treatment monitoring [30], as a twofold decrease in the serum MMP-9/TIMP-1 ratio correlated with decreased disease activity. Previously, it was demonstrated that IFN-beta was able to inhibit the production of MMPs by $\mathrm{T}$ lymphocytes [31].

Serum MMP-3 levels are higher during MS relapse than in remission [32]. This variation may be helpful in detecting disease activation. Stable MS patients have lower mean serum MMP-3 levels than myasthenia gravis (MG) patients and healthy controls [33]. Also, intrathecal MMP-2 production was increased in relapsing-remitting MS patients [34].
Extracellular matrix metalloproteinase inducer (EMMPRIN, CD147), a member of the Ig superfamily, is upregulated on peripheral leukocytes before the onset of EAE, which is an experimental model for MS. In EAE brain sections, EMMPRIN expression was localized with MMP-9 protein and activity. The increased EMMPRIN level was also characteristic of brain samples from MS subjects, particularly in plaque-containing areas. EMMPRIN regulates leukocyte trafficking through increasing MMP activity. EMMPRIN might therefore be a novel therapeutic target in MS [35].

The effect of intravenous IgG in MS is disputed, although it has been reported in an animal model that intravenous IgG might be effective as prophylaxis, preventing disease development, exerting its function by suppressing activation of MMPs- 2 and -9 by blocking MMP activities at the interface between the blood stream and CNS [36].

Tetracyclines are known to inhibit MMPs-2 and -9, and have been used in both EAE and MS patients, resulting in promising reduction of relapse rates [37, 38]. Also MMP-8 has been reported to play a role in various inflammatory conditions such as MS. Therefore, it is interesting to develop MMP-8 selective inhibitors. One approach is immobilized enzyme reactors, allowing a simple way to determine affinity and thus the ranking of the inhibiting potency of the compounds under study. The immobilized enzyme reactor was successfully used for the screening of known MMP-8 inhibitors in zonal chromatography and inhibition experiments [39].

To summarize available clinical data on MMPs in MS in one single hypothesis on how MMPs play their role in MS (table 1), it is reasonable to assume that increased MMP activity enhances MS plaque formation and clinical deterioration through increased MMP ability to traverse the blood-brain barrier and promotion of neuroinflammation, followed by increased destructive catalytic activity inside the CNS resulting in demyelination and neurotoxicity $[1,10,40]$. It is not known whether this increased MMP activity is a causative primary plaque formation phenomenon in MS or a secondary result of other pathophysiological steps.

\section{Serum Levels of MMPs in MG}

MG is an autoimmune disorder which causes skeletal muscle weakness. Antibodies against the acetylcholine receptor (AChR) are present in $85 \%$ of patients with generalized MG (GMG) and in about $40 \%$ of patients with 
Table 1. Summary of the action of the different MMPs in the various neurological conditions discussed in this review

\begin{tabular}{|c|c|c|c|c|}
\hline $\begin{array}{l}\text { Neurological } \\
\text { disorder }\end{array}$ & MMPs involved & Serum level & Possible role & $\begin{array}{l}\text { Possible future target of } \\
\text { MMP inhibitor treatment }\end{array}$ \\
\hline MS & $\begin{array}{l}3,8,9 / \text { TIMP-1 } \\
8,9\end{array}$ & $\begin{array}{l}\text { elevated during relapses } \\
\text { reduced after treatment }\end{array}$ & $\begin{array}{l}\text { pathogenic } \\
\text { markers of treatment response }\end{array}$ & yes \\
\hline MG & $2,3,9$ & elevated & pathogenic & yes \\
\hline Stroke & $\begin{array}{l}3 \\
9 / \mathrm{TIMP}-1 \\
3\end{array}$ & $\begin{array}{l}\text { reduced in acute stroke } \\
\text { elevated }\end{array}$ & $\begin{array}{l}\text { pathogenic } \\
\text { marker of worse outcome } \\
\text { carotid atherosclerosis }\end{array}$ & $\begin{array}{l}\text { unknown } \\
\text { yes }\end{array}$ \\
\hline ALS & $1,2,9 /$ TIMP-1 & elevated & pathogenic & yes \\
\hline $\mathrm{AD}$ & $2,3,10$ & elevated & pathogenic & unknown \\
\hline Migraine & $\begin{array}{l}2 \\
\text { 9/TIMP-1 }\end{array}$ & $\begin{array}{l}\text { elevated } \\
\text { elevated }\end{array}$ & $\begin{array}{l}\text { pathogenic in migraine with aura } \\
\text { pathogenic in migraine without aura }\end{array}$ & $\begin{array}{l}\text { unknown } \\
\text { unknown }\end{array}$ \\
\hline Epilepsy & 9 & & pathogenic & unknown \\
\hline
\end{tabular}

ocular MG (OMG) [41-43]. Most patients with OMG develop GMG during the first 2 years, but $15 \%$ remain with purely ocular symptoms for the entire course [42]. MG with AChR antibodies is known as seropositive MG (SPMG). Thymoma is present in 15\% of MG patients [44]. AChR antibodies impair neuromuscular transmission by complement-mediated postsynaptic membrane damage, direct blockade of ligand-receptor interaction, and/or by cross-linking of AChR and increased degradation [41, 45]. Antibodies to muscle-specific kinase (MuSK) are observed in a minority of MG patients $[46,47]$. MuSK is a key signaling protein controlling AChR clustering and the formation of the neuromuscular junction. Agrin interaction with MuSK leads to the clustering of AChR [48, 49]. MG without detectable antibodies to AChR and MuSK is termed seronegative MG (SNMG). Several other autoantibodies, against titin, ryanodine receptor, myo$\sin$, and $\alpha$-actin, have been detected in sera from MG patients. These antibodies are associated with MG subtype and disease severity [50].

In an in vitro study, it was previously shown that MMP-9 is targeted by immunomodulated autoreactive T cells from MG-immunized mice [51]. Elevated serum MMP-3 levels are present in both SPMG and SNMG [52]. High serum MMP-3 levels were confirmed in another MG cohort, where the patients had OMG or MG with ocular muscle predominance [53]. Interestingly, in this cohort, females had significantly lower serum MMP-3 concentrations than males, and male patients were overrepresented among those with higher serum MMP-3 concentrations (male:female ratio $=4: 1$ ). The elevated MMP-3 levels did not correlate with the presence of AChR antibodies, age of onset, or thymus pathology. MMP-3 concentration in the MG cohort was higher than in control autoimmune and non-immune neurological disorders [33]. Serum MMP-2 and MMP-9 concentrations were higher for both the GMG and OMG groups compared to healthy controls. The presence of MMP-2 did not correlate with the occurrence of AChR antibodies. No significant age or gender difference, nor difference between SPMG and SNMG patients, was observed for MMP-9.

The mechanism by which these MMPs exert their action in MG is not known (table 1). However, one could hypothesize about their role in regulating agrin levels through MMP-MMP interaction. We know that MMP-2 and MMP-3 are able to activate MMP-9 [54-57], whereas MMP-2 and MMP-9 are potent activators of MMP-3 [58]. Agrin is a substrate for MMP-3 [59]. MMP-3 null mice have alterations in their neuromuscular junctions, with increased AChR staining at the endplate, an increased number of junctional folds, and increased agrin concentration [60]. These observations indicate that MMP-3 controls the structure of the neuromuscular junction via regulation of agrin levels. Elevated MMP levels in MG may thus be involved in promoting autoimmunity, but also in the pathophysiological steps causing damage to the neuromuscular junction through increased MMP-2, -3 , and -9 activity. 


\section{Serum Levels of MMPs in Acute Ischemic Stroke}

Acute ischemic stroke is caused by blood vessel occlusion disrupting the blood supply to the brain causing tissue damage. Its treatment is time dependent and technically and logistically demanding [61]. Higher serum MMP-9 concentrations in the acute phase correlate with larger infarct volume, higher stroke severity, and worse functional outcome [62]. MMP-9 was also a predictor of intracerebral hemorrhage development in patients treated with thrombolytic therapy. In a cohort study of elderly men [9], serum MMP-9 and TIMP-1 levels correlated with the risk of all-cause mortality, while TIMP-1 levels were mainly related to cardiovascular mortality and stroke risk. The authors suggested MMP-9 and TIMP-1 levels as relevant markers for an altered extracellular matrix metabolism of clinical significance. It was previously demonstrated that several MMPs are increased in ischemic stroke [63].

In a group of consecutively collected acute stroke patients, none had elevated serum MMP-3 levels [33]. Mean serum MMP-3 concentration in the acute stroke group was reduced compared to healthy controls, and also to disease controls. MMP-3 may thus play a role in the pathophysiology of acute stroke. MMP-3 testing might therefore be useful as an indicator of acute cerebral ischemia with brain tissue damage in the very early phase where other diagnostic means, including MRI, are often inconclusive.

Studies have shown conflicting results regarding MMP-3 and blood vessel pathology. It is, however, possible to hypothesize on the mechanism by which MMPs are linked to cerebral ischemia and stroke (table 1). High serum MMP-3 levels have been linked to atherosclerosis in the carotid arteries [64] and to higher mortality following acute cerebral hemorrhage [65]. Low serum MMP-3 levels were seen in stroke patients with dolichoectasia [66]. Whether the low MMP-3 levels in acute stroke patients are primarily linked to the thromboembolic mechanisms that cause stroke or are a result of increased activation and consumption of MMP-3 in the tissue damage process following acute stroke is unknown. However, following cerebral ischemia and reperfusion in acute experimental stroke in rats, MMP-3 is activated causing cleavage of brain agrin as a step in the tissue damaging process [67]. This indicates increased activation and consumption of MMP-3 during the tissue damage immediately following an acute stroke. In experimental stroke, animals treated with MMP inhibitors 1 week after stroke had larger infarctions than those treated 2 weeks after stroke [68], indicating that MMPs might play a pro-ischemic role during the early stages of stroke and a constructive role during the repair phase after stroke.

\section{Serum Levels of MMPs in Other Neurological Disorders}

In neurodegenerative diseases such as amyotrophic lateral sclerosis (ALS) and Alzheimer's dementia (AD), MMPs may be useful as disease markers. In one study, serum MMP-2 concentration correlated with ALS progression [69]. In another study, serum MMP-1, MMP-2, MMP-9, and TIMP-1 were increased in mild ALS cases, while MMP-9 was decreased in cerebrospinal fluid (CSF) [70]. In the superoxide dismutase transgenic mouse model of ALS, MMP-9 deficiency improved both life expectancy and neuronal death [71]. Also in the same model, treatment with MMP inhibitors had the same beneficial results [72].

A recent study on $\mathrm{AD}$ found that MMP-3 was elevated in serum and CSF [73]. MMP-2 in CSF was significantly decreased, while levels in serum remained unchanged. MMP-9 was significantly decreased, whereas MMP-10 was unchanged in serum, and none of them could be detected in CSF.

A pathogenic role and a consistent diagnostic pattern of MMPs in neurodegenerative disorders remain to be established (table 1).

Migraine patients with and without aura have increased serum MMP-2 activity. The serum MMP-9/ TIMP-1 ratio was higher in migraine without aura compared to migraine with aura, which may reflect pathophysiological differences between these two conditions [74] (table 1).

MMP-9 has been implicated in the pathogenesis of epilepsy and epileptic seizures in animal models, and also in experimental therapeutic approaches to epilepsy [7577]. Any role of MMP-9 in clinical epileptology is still to be established. Serum MMP-3 concentration in epilepsy patients did not differ from that in healthy controls [33] (table 1). 


\section{References}

1 Yong VW, Agrawal SM, Stirling D: Targeting MMPs in acute and chronic neurological conditions. Neurotherapeutics 2007;4:580-589.

-2 Morrison CJ, Butler GS, Rodríguez D, Overall CM: Matrix metalloproteinase proteomics: substrates, targets, and therapy. Curr Opin Cell Biol 2009;21:645-653.

- 3 Murphy G, Nagase H: Progress in matrix metalloproteinase research. Mol Aspects Med 2008;29:290-308.

-4 Bode W, Fernandez-Catalan C, Grams F, Gomis-Rüth FX, Nagase $\mathrm{H}$, Tschesche $\mathrm{H}$, Maskos K: Insights into MMP-TIMP interactions. Ann NY Acad Sci 1999;878:73-91.

5 Sternlicht MD, Werb Z: How matrix metalloproteinases regulate cell behavior. Annu Rev Cell Dev Biol 2001;17:463-516.

-6 Michaluk P, Kaczmarek L: Matrix metalloproteinase-9 in glutamate-dependent adult brain function and dysfunction. Cell Death Differ 2007;14:1255-1258.

7 Greene J, Wang M, Liu YE, Raymond LA, Rosen C, Shi YE: Molecular cloning and characterization of human tissue inhibitor of metalloproteinase 4. J Biol Chem 1996;271: 30375-30380.

-8 Gomez DE, Alonso DF, Yoshiji H, Thorgeirsson UP: Tissue inhibitors of metalloproteinases: structure, regulation and biological functions. Eur J Cell Biol 1997;74:111-122.

\9 Hansson J, Vasan RS, Arnlöv J, Ingelsson E, Lind L, Larsson A, Michaëlsson K, Sundström J: Biomarkers of extracellular matrix metabolism (MMP-9 and TIMP-1) and risk of stroke, myocardial infarction, and causespecific mortality: cohort study. PLoS One 2011;6:e16185.

-10 Yong VW, Zabad RK, Agrawal S, Goncalves Dasilva A, Metz LM: Elevation of matrix metalloproteinases (MMPs) in multiple sclerosis and impact of immunomodulators. J Neurol Sci 2007;259:79-84.

11 Witzemann V: Development of the neuromuscular junction. Cell Tissue Res 2006;326: 263-271.

- 12 La Russa A, Cittadella R, De Marco EV, Valentino P, Andreoli V, Trecroci F, Latorre V, Gambardella A, Quattrone A: Single nucleotide polymorphism in the MMP-9 gene is associated with susceptibility to develop multiple sclerosis in an Italian case-control study. J Neuroimmunol 2010;225:175-179.

-13 Arakaki PA, Marques MR, Santos MC: MMP-1 polymorphism and its relationship to pathological processes. J Biosci 2009;34: 313-320.

- 14 Kotajima L, Aotsuka S, Fujimani M, OkawaTakatsuji M, Kinoshita M, Sumiya M, Obata $\mathrm{K}$ : Increased levels of matrix metalloproteinase-3 in sera from patients with active lupus nephritis. Clin Exp Rheumatol 1998;16:409415.

15 Chen WS, Lin KC, Chen CH, Liao HT, Wang HP, Li WY, Lee HT, Tsai CY, Chou CT: Autoantibody and biopsy grading are associat- ed with expression of ICAM-1, MMP-3, and TRAIL in salivary gland mononuclear cells of Chinese patients with Sjogren's syndrome. J Rheumatol 2009;36:989-996.

16 Matache C, Stefanescu M, Dragomir C, Tanaseanu S, Onu A, Ofiteru A, Szegli G: Matrix metalloproteinase- 9 and its natural inhibitor TIMP-1 expressed or secreted by peripheral blood mononuclear cells from $\mathrm{pa}$ tients with systemic lupus erythematosus. J Autoimmun 2003;20:323-331.

17 Kim WU, Min SY, Cho ML, Hong KH, Shin YJ, Park SH, Cho CS: Elevated matrix metalloproteinase- 9 in patients with systemic sclerosis. Arthritis Res Ther 2005;7:R71-R79.

18 Gruber BL, Sorbi D, French DL, Marchese MJ, Nuovo GJ, Kew RR, Arbeit LA: Markedly elevated serum MMP-9 (gelatinase B) levels in rheumatoid arthritis: a potentially useful laboratory marker. Clin Immunol Immunopathol 1996;78:161-171.

19 Konttinen YT, Halinen S, Hanemaaijer R, Sorsa T, Hietanen J, Ceponis A, Xu JW, Manthorpe R, Whittington J, Larsson A, Salo T, Kjeldsen L, Stenman UH, Eisen AZ: Matrix metalloproteinase (MMP)-9 type IV collagenase/gelatinase implicated in the pathogenesis of Sjogren's syndrome. Matrix Biol 1998; 17:335-347.

20 Zucker S, Lysik RM, Zarrabi MH, Greenwald RA, Gruber B, Tickle SP, Baker TS, Docherty AJ: Elevated plasma stromelysin levels in arthritis. J Rheumatol 1994;21:2329-2333.

21 Levin VA, Phuphanich S, Yung WK, Forsyth PA, Maestro RD, Perry JR, Fuller GN, Baillet M: Randomized, double-blind, placebo-controlled trial of marimastat in glioblastoma multiforme patients following surgery and irradiation. J Neurooncol 2006;78:295-302.

22 Compston A, Coles A: Multiple sclerosis. Lancet 2008;359:1221-1231.

23 Stinissen P, Raus J, Zhang J: Autoimmune pathogenesis of multiple sclerosis: role of autoreactive Tlymphocytes and new immunotherapeutic strategies. Crit Rev Immunol 1997;7:33-75.

24 Goodin DS: The causal cascade to multiple sclerosis: a model for MS pathogenesis. PLoS One 2009;4:e4565.

25 Ebers GC: Environmental factors and multiple sclerosis. Lancet Neurol 2008;7:268-277.

-26 Burrell AM, Handel AE, Ramagopalan SV, Ebers GC, Morahan JM: Epigenetic mechanisms in multiple sclerosis and the major histocompatibility complex (MHC). Discov Med 2011;11:187-196.

27 Alexander JS, Harris MK, Wells SR, Mills G, Chalamidas K, Ganta VC, McGee J, Jennings $\mathrm{MH}$, Gonzalez-Toledo E, Minagar A: Alterations in serum MMP-8, MMP-9, IL-12p40 and IL-23 in multiple sclerosis patients treated with interferon-beta1b. Mult Scler 2010;1: 801-809.

28 Weaver A, Goncalves DaSilva A, Nuttall RK, Edwards DR, Shapiro SD, Rivest S, Yong
VW: An elevated matrix metalloproteinase (MMP) in an animal model of multiple sclerosis is protective by affecting Th1/Th2 polarization. FASEB J 2005;19:1668-1670.

29 Thorne M, Moore CS, Robertson GS: Lack of TIMP-1 increases severity of experimental autoimmune encephalomyelitis: effects of darbepoetin alfa on TIMP-1 null and wildtype mice. J Neuroimmunol 2009;211:92100.

-30 Garcia-Montojo M, Dominguez-Mozo MI, de las Heras V, Bartolome M, Garcia-Martinez A, Arroyo R, Alvarez-Lafuente R: Neutralizing antibodies, MxA expression and MMP-9/TIMP-1 ratio as markers of bioavailability of interferon-beta treatment in multiple sclerosis patients: a two-year followup study. Eur J Neurol 2010;17:470-478.

-31 Leppert D, Waubant E, Burk MR, Oksenberg JR, Hauser SL: Interferon beta-1b inhibits gelatinase secretion and in vivo migration of human T cells: a possible mechanism for treatment efficacy in multiple sclerosis. Ann Neurol 1996;40:846-852.

32 Kanesaka T, Mori M, Hattori T, Oki T, Kuwabara S: Serum matrix metalloproteinase-3 levels correlate with disease activity in relapsing-remitting multiple sclerosis. J Neurol Neurosurg Psychiatry 2006;77:185-188.

33 Luckman S, Gilhus NE, Romi F: Matrix metalloproteinases-3 in myasthenia gravis compared to other neurological disorders and healthy controls. Autoimmune Dis 2011; 2011:151258.

34 Fainardi E, Castellazzi M, Tamborino C, Trentini A, Manfrinato MC, Baldi E, Tola MR, Dallocchio F, Granieri E, Bellini T: Potential relevance of cerebrospinal fluid and serum levels and intrathecal synthesis of active matrix metalloproteinase-2 (MMP-2) as markers of disease remission in patients with multiple sclerosis. Mult Scler 2009;15:547554.

-35 Agrawal SM, Silva C, Tourtellotte WW, Yong VW: EMMPRIN: a novel regulator of leukocyte transmigration into the CNS in multiple sclerosis and experimental autoimmune encephalomyelitis. J Neurosci 2011;31:669677.

-36 Niimi N, Kohyama K, Kamei S, Matsumoto Y: Intravenous immunoglobulin therapy prevents development of autoimmune encephalomyelitis and suppresses activation of matrix metalloproteinases. Neuropathology 2011;31:392-400.

-37 Zabad RK, Metz LM, Todoruk TR, Zhang Y, Mitchell JR, Yeung M, Patry DG, Bell RB, Yong VW: The clinical response to minocycline in MS is accompanied by immune changes. Mult Scler 2007;13:517-526.

- $38 \mathrm{Hu} \mathrm{W}$, Metselaar J, Ben LH, Cravens PD, Singh MP, Frohman EM, Eagar TN, Racke MK, Kieseier BC, Stüve O: PEG minocycline-liposomes ameliorate CNS autoimmune disease. PLoS One 2009;4:e4151. 
\39 Mazzini F, Nuti E, Petri A, Rossello A: Immobilization of matrix metalloproteinase 8 (MMP-8) for online drug screening. J Chromatogr B Analyt Technol Biomed Life Sci 2011;879:756-762.

40 Yong VW: Differential mechanisms of action of interferon- $\beta$ and glatiramer acetate in MS. Neurology 2002;59:802-808.

$\checkmark 4$ Lindstrøm JM, Seybold ME, Lennon VA, Whittingham S, Duane DD: Antibody to acetylcholine receptor in myasthenia gravis: prevalence, clinical correlates, and diagnostic value. 1975. Neurology 1998;51:933-939.

-42 Evoli A, Batocchi AP, Minisci C, Di Schino C, Tonali P: Therapeutic options in ocular myasthenia gravis. Neuromuscul Disord 2001;11:208-216.

43 Luchanok U, Kaminski HJ: Ocular myasthenia: diagnostic and treatment recommendations and the evidence base. Curr Opin Neurol 2008;21:8-15.

44 Wilcox N: Myasthenia gravis. Curr Opin Immunol 1993;5:910-917.

45 Li Z, Forester N, Vincent A: Modulation of acetylcholine receptor function in TE671 (rhabdomyocyosarcoma) cells by non-AchR ligands: possible relevance to seronegative myasthenia gravis. J Neuroimmunol 1996; 64:179-183

-46 Hoch W, McConville J, Helms S, NewsomDavis J, Melms A, Vincent A: Auto-antibodies to the receptor tyrosine kinase MuSK in patients with myasthenia gravis without acetylcholine receptor antibodies. Nat Med 2001;7:365-368.

-47 McConville J, Farrugia ME, Beeson D, Kishore U, Metcalfe R, Newsom-Davis J, Vincent A: Detection and characterization of MuSK antibodies in seronegative myasthenia gravis. Ann Neurol 2004;55:580-584.

-48 Fuhrer C, Sugiyama JE, Taylor RG, Hall ZW: Association of muscle-specific kinase MuSK with the acetylcholine receptor in mammalian muscle. EMBO 1997;16:4951-4960.

49 Borges LS, Ferns M: Agrin-induced phosphorylation of the acetylcholine receptor regulates cytoskeletal anchoring and clustering. J Cell Biol 2001;153:1-11.

50 Romi F, Skeie GO, Gilhus NE, Aarli JA: Striational antibodies in myasthenia gravis: reactivity and possible clinical significance. Arch Neurol 2005;62:442-446.

-51 Faber-Elmann A, Grabovsky V, Dayan M, Sela M, Alon R, Mozes E: An altered peptide ligand inhibits the activities of matrix metalloproteinase-9 and phospholipase $\mathrm{C}$, and inhibits $\mathrm{T}$ cell interactions with VCAM-1 induced in vivo by a myasthenogenic $\mathrm{T}$ cell epitope. FASEB J 2001;15:187-194.

52 Romi F, Gilhus NE, Luckman S: Serum matrix metalloproteinase-3 (MMP-3) levels are elevated in myasthenia gravis. J Neuroimmunol 2008;195:96-99.

-53 Helgeland G, Petzold A, Luckman SP, Gilhus NE, Plant GT, Romi F: Matrix metalloproteinases in myasthenia gravis. Eur Neurol 2011;65:53-58
54 Chakraborti S, Mandal M, Das S, Mandal A, Chakraborti T: Regulation of matrix metalloproteinases: an overview. Mol Cell Biochem 2003;253:269-285.

55 Ogata Y, Enghild JJ, Nagase H: Matrix metalloproteinase 3 (stromelysin) activates the precursor for the human matrix metalloproteinase 9. J Biol Chem 1992;267:3581-3584.

56 Vempati P, Karagiannis ED, Popel AS: A biochemical model of matrix metalloproteinase 9 activation and inhibition. J Biol Chem 2007;282:37585-37596.

57 Sternlicht MD, Werb Z: ECM proteinases; in Kreis T, Vale R (eds): Guidebook to the Extracellular Matrix and Adhesion Proteins. New York, Oxford University Press, 1999, pp 503-562.

58 VanSaun M, Humburg BC, Arnett MG, Pence M, Werle MJ: Activation of Matrix Metalloproteinase-3 is altered at the frog neuromuscular junction following changes in synaptic activity. Dev Neurobiol 2007;67: 1488-1497.

59 VanSaun M, Werle MJ: Matrix metalloproteinase-3 removes agrin from synaptic basal lamina. J Neurobiol 2000;43:140-149.

60 VanSaun M, Herrera AA, Werle MJ: Structural alterations at the neuromuscular junctions of matrix metalloproteinase 3 null mutant mice. J Neurocytol 2002;32:1129-1142.

61 Rymner MM, Akhtar N, Martin C, Summers D: Management of acute ischemic stroke: time is brain. Mo Med 2010;107:333-337.

62 Ramos-Fernandez M, Bellolio MF, Stead LG: Matrix metalloproteinase- 9 as a marker for acute ischemic stroke: a systematic review. J Stroke Cerebrovasc Dis 2011;20:47-54

63 Rosell A, Alvarez-Sabin J, Arenillas JF, Rovira $\mathrm{A}$, Delgado $\mathrm{P}$, Fernàndez-Cadenas I, Penalba A, Molina CA, Montaner J: A matrix metalloproteinase protein array reveals a strong relation between MMP-9 and MMP13 with diffusion-weighted image lesion increase in human stroke. Stroke 2005;36: 1415-1420.

64 Lien LM, Hsieh YC, Bai CH, Chen WH, Chiu HC, Hsieh FI, Shyu KG, Chiou HY, Hsu CY: Association of blood active matrix metalloproteinase- 3 with carotid plaque score from a community population in Taiwan. Atherosclerosis 2010;212:595-600.

65 Alvarez-Sabín J, Delgado P, Abilleira S, Molina CA, Arenillas J, Ribó M, Santamarina E, Quintana M, Monasterio J, Montaner J: Temporal profile of matrix metalloproteinases and their inhibitors after spontaneous intracerebral hemorrhage: relationship to clinical and radiological outcome. Stroke 2004;35 1316-1322.

66 Pico F, Jacob MP, Labreuche J, Soufir N, Touboul PJ, Benessiano J, Cambien F, Grandchamp B, Michel JB, Amarenco P: Matrix metalloproteinase- 3 and intracranial arterial dolichoectasia. Ann Neurol 2010;67:508515 .
67 Solé S, Petegnief V, Gorina R, Chamorro A, Planas AM: Activation of matrix metalloproteinase- 3 and agrin cleavage in cerebral ischemia/reperfusion. J Neuropathol Exp Neurol 2004;63:338-349.

68 Zhao BQ, Tejima E, Lo EH: Neurovascular proteases in brain injury, hemorrhage and remodeling after stroke. Stroke 2007;38 (suppl 2):748-752.

-69 Sokolowska B, Jozwik A, Niebroj-Dobosz I, Janik P, Kwiecinski H: Evaluation of matrix metalloproteinases in serum of patients with amyotrophic lateral sclerosis with pattern recognition methods. J Physiol Pharmacol 2009;60:117-120.

70 Niebroj-Dobosz I, Janik P, Sokołowska B, Kwiecinski H: Matrix metalloproteinases and their tissue inhibitors in serum and cerebrospinal fluid of patients with amyotrophic lateral sclerosis. Eur J Neurol 2010; 17:226-231

71 Kiaei M, Kipiani K, Calingasan NY, Wille E, Chen J, Heissig B, Rafii S, Lorenzl S, Beal MF: Matrix metalloproteinase- 9 regulates TNFalpha and FasL expression in neuronal, glial cells and its absence extends life in a transgenic mouse model of amyotrophic lateral sclerosis. Exp Neurol 2007;205:74-81.

72 Lorenzl S, Narr S, Angele B, Krell HW, Gregorio J, Kiaei M, Pfister HW, Beal MF: The matrix metalloproteinases inhibitor Ro 282653 [correction of Ro 26-2853] extends survival in transgenic ALS mice. Exp Neurol 2006;200:166-171.

73 Horstmann S, Budig L, Gardner H, Koziol J, Deuschle M, Schilling C, Wagner S: Matrix metalloproteinases in peripheral blood and cerebrospinal fluid in patients with $\mathrm{Alz}$ heimer's disease. Int Psychogeriatr 2010;22: 966-972.

74 Martins-Oliveira A, Speciali JG, Dach F, Marcaccini AM, Gonçalves FM, Gerlach RF, Tanus-Santos JE: Different circulating metalloproteinases profiles in women with migraine with and without aura. Clin Chim Acta 2009;408:60-64.

75 Wilczynski GM, Konopacki FA, Wilczek E, Lasiecka Z, Gorlewicz A, Michaluk P, Wawrzyniak M, Malinowska M, Okulski P, Kolodziej LR, Konopka W, Duniec K, Mioduszewska B, Nikolaev E, Walczak A, Owczarek D, Gorecki DC, Zuschratter W, Ottersen OP, Kaczmarek L: Important role of matrix metalloproteinase 9 in epileptogenesis. J Cell Biol 2008;180:1021-1035.

-76 Takács E, Nyilas R, Szepesi Z, Baracskay P, Karlsen B, Røsvold T, Bjørkum AA, Czurkó A, Kovács Z, Kékesi AK, Juhász G: Matrix metalloproteinase-9 activity increased by two different types of epileptic seizures that do not induce neuronal death: a possible role in homeostatic synaptic plasticity. Neurochem Int 2010;56:799-809.

-77 Yin P, Yang L, Zhou HY, Sun RP: Matrix metalloproteinase- 9 may be a potential therapeutic target in epilepsy. Med Hypotheses 2011;76:184-186. 